\title{
Technological, Sensory, and Hypoglycemic Effects of Quinoa Flour Incorporation into Biscuits
}

\author{
Amnah Mohammed Alsuhaibani (D), Amal Nassir Alkuraieef (iD, \\ Moneera Othman Aljobair $(\mathbb{D}$, and Amal Hassan Alshawi $\mathbb{D}$
}

\begin{abstract}
Department of Physical Sport Science, College of Education, Princess Nourah bint Abdulrahman University, P.O. Box 84428, Riyadh 11671, Saudi Arabia
\end{abstract}

Correspondence should be addressed to Amnah Mohammed Alsuhaibani; amalsuhaibani@pnu.edu.sa

Received 31 August 2021; Revised 14 December 2021; Accepted 27 December 2021; Published 5 January 2022

Academic Editor: Massimo Lucarini

Copyright (c) 2022 Amnah Mohammed Alsuhaibani et al. This is an open access article distributed under the Creative Commons Attribution License, which permits unrestricted use, distribution, and reproduction in any medium, provided the original work is properly cited.

\begin{abstract}
Background. Biscuits are consumed by all of society in the world. Incorporation of different ratios of quinoa flour into wheat flour for the production of biscuits is needed for the production of functional foods. Objective. This study aimed to evaluate the incorporation of $12.5 \%$ or $25 \%$ quinoa flour into biscuit production, evaluate rheological and sensory characteristics, and investigate the effect of the consumption of $20 \%$ cooked biscuits on diabetic rats. Design. The gross chemical composition, total carotenoids, phenolic and flavonoids of wheat flour and quinoa flour, and the rheological properties of the control, $12.5 \%$ quinoa, and $25 \%$ quinoa biscuit dough were determined. The effects of consumption of $12.5 \%$ quinoa and $25 \%$ quinoa biscuits on diabetic rats were investigated. Results. Quinoa flour had significantly higher levels of the gross chemical composition except for carbohydrate and increased phenolic compound and flavonoids content than those in wheat flour. Increasing the amount of quinoa flour in the biscuits could increase the farinograph and extensograph values of the dough. Biological results showed that the highest improvement in nutritional values appeared in the diabetic rat group, which consumed 25\% quinoa biscuit for 60 days. The consumption of $12.5 \%$ quinoa biscuit and $25 \%$ quinoa biscuit showed a decline in blood glycosylated hemoglobin and glucose and an elevation in insulin levels compared with the positive control diabetic rat group. Discussion and Conclusion. It is encouraging to replace wheat flour with quinoa flour in biscuit manufacturing owing to positive effects on both the technological properties and sensory evaluation of biscuits. The increase of quinoa flour up to $25 \%$ had favorable nutritional values and hypoglycemic effects.
\end{abstract}

\section{Introduction}

Quinoa (Chenopodium quinoa Willd.) is a member of the Chenopodiaceae family and acts as pseudocereal due to yield grains and consumed as cereals or flour products $[1,2]$. Quinoa has high nutritional value and acts as a complete food. It offers all essential amino acids, such as methionine, histidine, and lysine; essential fatty acids, such as oleic and linoleic acids; and dietary fiber, which detoxify the waste products and toxins. It also has a wide range of minerals and vitamins, more than those present in cereals and legumes [3-7].

Quinoa has been cultivated worldwide as a new crop species directed at technological and commercial importance. It is used in cooking, baking, modified food products such as breakfast cereals, pasta, and cookies, industrial use of starch, protein, and saponin, and the pharmaceutical industry and animal feeding [1, 8-10].

Currently, quinoa is incorporated into wheat flour at a definite percentage for bakery production as cakes, bread, and biscuits to enrich the sensory characteristics of the baked goods, such as the aroma, taste, texture, and acceptability, in addition to increasing the nutritious and health benefits of baked products [11-13]. Quinoa is known as a functional food because it improves lipid parameters, triglycerides, and the glycemic index in addition to its beneficial components, such as vitamins and minerals, and is gluten free $[7,14]$. 
Biscuits are consumed by nearly all of society because of their low cost, availability, taste variation, and relatively long shelf life in addition to their good nutritional quality, which leads to the importance of increasing their protein, vitamin, and fiber content. It has been of interest to improve the nutritional and sensory quality of biscuits by incorporating functional foods, such as those in gluten-free biscuits. A $60 \%$ substitution of wheat flour with quinoa flour resulted in dark-colored cookies with increased hardness and decreased volume and chewiness, so the addition of quinoa flour should be not more than $50 \%$ to enhance nutritional and sensory properties [15-19].

Therefore, this study aimed to determine the incorporation of different ratios of quinoa flour into wheat flour for the production of biscuits, to evaluate the rheological and sensory characteristics, and investigate the effect of the consumption of $20 \%$ biscuits on diabetic rats.

\section{Materials and Methods}

Wheat flour, quinoa flour, sugar, salt, eggs, margarine, lecithin, baking powder, and vanillin were purchased from local markets. Twenty-eight albino rats weighing $120 \pm 7 \mathrm{~g}$ were provided by the experimental animals' center in the Research Center in Prince Sultan Military Medical City, Riyadh. Ethical guidelines for investigations involving experimental animals were followed throughout the study. The experiments were carried out with the help of the staff of the Scientific Research Center of the MSD at their experimental animal (REC AP2411/16A). The basal diet was formed [20].

The gross chemical composition of wheat flour and quinoa flour, including protein, lipids, fiber, ash, and moisture, was estimated according to AACC methods [21]. The carbohydrate content (\%) of wheat flour and quinoa flour was calculated.

The total phenolic compound content of wheat flour and quinoa flour was determined calorimetrically and expressed as gallic acid equivalents (gGAE/1000 g) [22]. The total carotenoid and flavonoid contents were determined spectrophotometrically according to standard methods [23]. The water-holding capacity and oil-holding capacity of wheat flour and quinoa flour were determined [24, 25].

The ingredients of different biscuit batters illustrated in Table 1 were mixed, rested for half an hour, laminated, shaped, and then, baked at $220^{\circ} \mathrm{C}$ for $15 \mathrm{~min}$ to prepare control, $12.5 \%$ quinoa representing $6.22 \%$ of dry ingredients of biscuit, and $25 \%$ quinoa biscuits representing $12.44 \%$ of dry ingredients of biscuit [26].

The rheological properties of the control, $12.5 \%$ quinoa, and $25 \%$ quinoa biscuit dough were determined by using Brabender farinograph and extensograph instruments according to the AACC method [21]. Sensory evaluation of the control, $12.5 \%$ quinoa, and $25 \%$ quinoa biscuits was conducted for appearance, texture, color, taste, odor, and overall acceptability by ten trained sensory panelists using a hedonic scale.

To investigate the antidiabetic effect, rats fed a basal diet and water ad libitum were allowed to adapt for one week. Rats were injected intraperitoneally with streptozotocin at a dose of $50 \mathrm{mg} / \mathrm{kg}$ body weight in $0.1 \mathrm{M}$ citrate buffer to induce diabetes, which was confirmed by the elevation of blood glucose samples on the third day. Rats were randomly divided into four groups as follows:

The positive control rat group consumed a basal diet. The control biscuit rat group consumed the basal diet containing $20 \%$ dried, powdered control biscuit.

The $12.5 \%$ quinoa biscuit rat group consumed the basal diet containing 20\% dried, powdered $12.5 \%$ quinoa biscuit.

The 25\% quinoa biscuit rat group consumed the basal diet containing $20 \%$ dried, powdered $25 \%$ quinoa biscuit.

Daily food intake and weekly body weight were recorded. The feed efficiency ratio (FER) was calculated.

Rats were sacrificed after 60 days to estimate hemoglobin, glycosylated hemoglobin, glucose, and insulin [27]. The obtained results of triplicate assays were statistically analyzed by analysis of variance (ANOVA), and significant differences among Duncan's multiple tests were determined using SPSS computer software.

\section{Results and Discussion}

The analysis of the wheat flour and quinoa flour samples used in the production of the control, $12.5 \%$ quinoa, and $25 \%$ quinoa biscuits is presented in Table 2. The wheat flour had significantly lower protein, lipids, fiber, ash, and energy levels than quinoa flour. On the other hand, wheat flour had higher contents of carbohydrate and moisture than quinoa flour. The results were in agreement with the results of many authors $[5,11,28,29]$. In contrast, quinoa flour had 58.3\% carbohydrate, $13.5 \%$ crude protein, $9.5 \%$ crude fiber, $1.2 \%$ total ash, and $11.2 \%$ moisture. Also, $12 \%$ protein, $6.5 \%$ lipid, $77 \%$ carbohydrate, and $3 \%$ mineral contents in quinoa grain were estimated [30]. The variation in the chemical composition of quinoa flour was related to the area of cultivation and germination period [17].

Table 3 shows that higher total carotenoid, phenolic, and flavonoid contents were observed in quinoa flour than in wheat flour. These values were consistent with many authors who reported that quinoa has significant amounts of antioxidant compounds such as carotenoids, polyphenols, and phenolic acids [4, 25, 31]. Quinoa has kaempferol, ferulic, gallic acids, isorhamnetin, and routine bioactive components [4, 32]. Polyphenols, phytosterols, isoflavones, and flavonoids have excellent antioxidant properties and contribute nutraceutical benefits. The quinoa flavonoid level was higher than that of blueberries, reaching levels similar to those of flavonoid-rich fruits [33, 34]. The variations in mineral, saponin, and total phenolic compound contents in quinoa are mainly due to methods of processing and cooking [35].

Table 4 shows that the differences between the waterholding capacity and oil-holding capacity of wheat flour and quinoa flour showed a significant difference. Wheat flour had significantly higher water- and oil-holding capacity 
TABLE 1: Ingredients in control, $12.5 \%$ quinoa, and 25\% quinoa biscuits.

\begin{tabular}{lcccccccccc}
\hline & $\begin{array}{c}\text { Wheat flour } \\
(\mathrm{g})\end{array}$ & $\begin{array}{c}\text { Quinoa flour } \\
(\mathrm{g})\end{array}$ & $\begin{array}{c}\text { Margarine } \\
(\mathrm{g})\end{array}$ & $\begin{array}{c}\text { Sugar } \\
(\mathrm{g})\end{array}$ & $\begin{array}{c}\text { Egg } \\
(\mathrm{g})\end{array}$ & $\begin{array}{c}\text { Lecithin } \\
(\mathrm{g})\end{array}$ & $\begin{array}{c}\text { Vanillin } \\
(\mathrm{g})\end{array}$ & $\begin{array}{c}\text { Salts } \\
(\mathrm{g})\end{array}$ & $\begin{array}{c}\text { Baking } \\
\text { powder }(\mathrm{g})\end{array}$ & $\begin{array}{c}\text { Water } \\
(\mathrm{g})\end{array}$ \\
\hline $\begin{array}{l}\text { Control biscuit } \\
\begin{array}{l}12.5 \% \text { quinoa } \\
\text { biscuit }\end{array}\end{array}$ & 200 & - & 32 & 60 & 100 & 1.2 & 0.5 & 1 & 7.2 & 30 \\
$\begin{array}{l}25 \% \text { quinoa } \\
\text { biscuit }\end{array}$ & 175 & 25 & 32 & 60 & 100 & 1.2 & 0.5 & 1 & 7.2 & 30 \\
\hline
\end{tabular}

TABle 2: Chemical composition of wheat flour and quinoa flour.

\begin{tabular}{lccccccc}
\hline $\begin{array}{l}\text { Nutrient } \\
\text { flour }\end{array}$ & $\begin{array}{c}\text { Protein } \\
(\mathrm{g} / 1000 \mathrm{~g})\end{array}$ & $\begin{array}{c}\text { Lipids } \\
(\mathrm{g} / 100 \mathrm{~g})\end{array}$ & $\begin{array}{c}\text { Fiber } \\
(\mathrm{g} / 100 \mathrm{~g})\end{array}$ & $\begin{array}{c}\text { Ash } \\
(\mathrm{g} / 100 \mathrm{~g})\end{array}$ & $\begin{array}{c}\text { Carbohydrate } \\
(\mathrm{g} / 100 \mathrm{~g})\end{array}$ & $\begin{array}{c}\text { Moisture } \\
(\mathrm{g} / 100 \mathrm{~g})\end{array}$ & $\begin{array}{c}\text { Energy } \\
(\mathrm{kcal} / 100 \mathrm{~g})\end{array}$ \\
\hline Wheat & $10.99 \pm 0.95 \mathrm{~b}$ & $1.45 \pm 0.08 \mathrm{~b}$ & $1.75 \pm 0.06 \mathrm{~b}$ & $1.69 \pm 0.07 \mathrm{~b}$ & $76.13 \pm 3.61 \mathrm{a}$ & $7.99 \pm 0.88 \mathrm{~b}$ & $361.53 \pm 4.66 \mathrm{~b}$ \\
Quinoa & $15.68 \pm 1.75 \mathrm{a}$ & $6.64 \pm 1.14 \mathrm{a}$ & $3.40 \pm 0.71 \mathrm{a}$ & $4.55 \pm 0.81 \mathrm{a}$ & $63.13 \pm 3.78 \mathrm{~b}$ & $6.60 \pm 0.75 \mathrm{a}$ & $379.02 \pm 3.55 \mathrm{a}$ \\
\hline
\end{tabular}

Mean values in each column having the same letter $(\mathrm{a}$ and $\mathrm{b})$ are nonsignificantly different at $P>0.05$.

TABLE 3: The total carotenoid, phenolic, and flavonoid content of wheat flour and quinoa flour.

\begin{tabular}{lccc}
\hline & Total carotenoid $(\mathrm{mg} / 100 \mathrm{~g})$ & Total phenolic compound $(\mathrm{mgGAE} / 100 \mathrm{~g})$ & Total flavonoids $(\mathrm{mg} / 100 \mathrm{~g})$ \\
\hline Wheat flour & $0.10 \pm 0.001 \mathrm{~b}$ & $30.18 \pm 5.41 \mathrm{~b}$ & $11.17 \pm 2.88 \mathrm{~b}$ \\
Quinoa flour & $1.45 \pm 0.25 \mathrm{a}$ & $66.45 \pm 8.15 \mathrm{a}$ & $32.14 \pm 6.11 \mathrm{a}$ \\
\hline
\end{tabular}

Mean values in each column having the same letter ( $\mathrm{a}$ and $\mathrm{b}$ ) are nonsignificantly different at $P>0.05$.

TABLE 4: Water-holding capacity and oil-holding capacity of wheat flour and quinoa flour.

\begin{tabular}{lcr}
\hline & Water-holding capacity $\left(\mathrm{g} \mathrm{H} \mathrm{H}_{2} \mathrm{O}\right)$ & Oil-holding capacity $(\mathrm{g}$ oil/g) \\
\hline Wheat flour & $6.33 \pm 0.22 \mathrm{a}$ & $8.01 \pm 0.66 \mathrm{a}$ \\
Quinoa flour & $2.88 \pm 0.07 \mathrm{~b}$ & $4.11 \pm 0.65 \mathrm{~b}$ \\
\hline
\end{tabular}

Mean values in each column having the same letter ( $\mathrm{a}$ and $\mathrm{b}$ ) are nonsignificantly different at $P>0.05$.

values than the values of quinoa flour. It is known that quinoa has expanded usages owing to its technological characteristics, such as solubility, gelation, water-holding capacity, and foaming, in addition to functional starch and omega-6, so it is appropriate to incorporate quinoa flour into wheat flour. The fiber of quinoa increased the water- and oilholding capacities of the four mixtures, improving the dough and baked product quality $[11,30,36]$.

The results in Table 5 show that the $12.5 \%$ quinoa biscuit and $25 \%$ quinoa biscuit had increased water absorption, arrival time, dough stability, and farinograph quality number values compared to the control biscuit. The highest farinograph parameters were observed in the $25 \%$ quinoa biscuits. These results were associated with hydrophilic carbohydrate, protein, and crude fiber contents in quinoa flour [28, 37-39]. In contrast, the obtained results disagreed with the decline in the arrival time, development, and stability of dough with increasing quinoa flour levels.

Increasing the quinoa flour in biscuit could increase extensibility, relative resistance, proportional number, and energy compared to the control biscuit. The values were highly significant in 25\% quinoa biscuit. Also, relative resistance and proportional number were highly significant in $25 \%$ quinoa biscuit compared to the control biscuit, as represented in Table 6 . The obtained results are correlated to the dilution of an interrelated dough gluten matrix. In particular, biscuits have high proportions of fat and sugar and a short mixing phase, but the gluten network developed in the tested biscuits is related to an increase in the incorporation of the quinoa flour into the cookies and starch gelatinization $[7,40]$.

The data in Table 7 show nonsignificant differences in appearance, texture, color, and taste score and a significant lowered score of flavor and acceptability between $12.5 \%$ quinoa and control biscuits. The $25 \%$ quinoa biscuit had a significant decrease in the tested sensory characteristics compared with the control biscuit. The $25 \%$ quinoa biscuit showed significantly lower values of appearance, texture, color, and taste score and nonsignificant difference of flavor and acceptability compared to $12.5 \%$ quinoa biscuit. Generally, increasing the amount of quinoa flour in the biscuits affected their sensory evaluation due to the high levels of protein in quinoa flour, which affected the texture, flavor, and acceptability of the biscuits. These changes in sensory quality were attributed to the formation of hydrogen bonds among the hydroxyl carbonyl, amide hydroxyl groups, and polar groups of the other ingredients of the biscuit flour. Additionally, the increased protein content in quinoa flour formed tiny, compact bubbles in the dough structure, hence producing biscuit hardness $[41,42]$. On the other hand, the 
TABLE 5: Farinograph parameters of control biscuit, 12.5\% quinoa biscuit, and 25\% quinoa biscuit.

\begin{tabular}{lccccc}
\hline & $\begin{array}{c}\text { Water absorption } \\
(\%)\end{array}$ & $\begin{array}{c}\text { Arrival time } \\
(\mathrm{min})\end{array}$ & $\begin{array}{c}\text { Dough development time } \\
(\mathrm{min})\end{array}$ & $\begin{array}{c}\text { Dough stability } \\
(\mathrm{min})\end{array}$ & $\begin{array}{c}\text { Farinograph quality } \\
\text { number }\end{array}$ \\
\hline $\begin{array}{l}\text { Control biscuit } \\
\begin{array}{l}12.5 \% \text { quinoa } \\
\text { biscuit }\end{array}\end{array}$ & $56.61 \pm 1.41 \mathrm{c}$ & $1.30 \pm 0.11 \mathrm{c}$ & $3.01 \pm 0.22 \mathrm{~b}$ & $4.32 \pm 0.40 \mathrm{~b}$ & $132 \pm 3.41 \mathrm{c}$ \\
$\begin{array}{l}25 \% \text { quinoa } \\
\text { biscuit }\end{array}$ & $62.55 \pm 2.14 \mathrm{ab}$ & $2.23 \pm 0.18 \mathrm{~b}$ & $4.31 \pm 0.59 \mathrm{ab}$ & $6.98 \pm 1.11 \mathrm{a}$ & $156 \pm 4.98 \mathrm{~b}$ \\
& $67.01 \pm 3.11 \mathrm{a}$ & $3.55 \pm 0.44 \mathrm{a}$ & $5.03 \pm 0.65 \mathrm{a}$ & $7.35 \pm 1.44 \mathrm{a}$ & $167 \pm 6.35 \mathrm{a}$ \\
\hline
\end{tabular}

Mean values in each column having the same letter ( $\mathrm{a}$ and $\mathrm{b}$ ) are nonsignificantly different at $P>0.05$.

TABLE 6: Extensograph parameters of control biscuit, 12.5\% quinoa biscuit, and 25\% quinoa biscuit.

\begin{tabular}{lcccc}
\hline & Extensibility $(\mathrm{mm})$ & Relative resistance $(\mathrm{BU})$ & Proportional number & Energy $\left(\mathrm{cm}^{2}\right)$ \\
\hline Control biscuit & $163 \pm 5.51 \mathrm{c}$ & $490 \pm 10.15 \mathrm{c}$ & $2.75 \pm 0.23 \mathrm{~b}$ & $108 \pm 6.77 \mathrm{c}$ \\
$12.5 \%$ quinoa biscuit & $182 \pm 4.57 \mathrm{~b}$ & $538 \pm 8.61 \mathrm{ab}$ & $3.41 \pm 0.66 \mathrm{a}$ & $119 \pm 5.66 \mathrm{~b}$ \\
$25 \%$ quinoa biscuit & $193 \pm 2.15 \mathrm{a}$ & $550 \pm 6.71 \mathrm{a}$ & $3.01 \pm 0.44 \mathrm{a}$ & $127 \pm 2.11 \mathrm{a}$ \\
\hline
\end{tabular}

Mean values in each column having the same letter ( $\mathrm{a}$ and $\mathrm{b}$ ) are nonsignificantly different at $P>0.05$.

TABLE 7: Sensory evaluation of control biscuit, $12.5 \%$ quinoa biscuit, and 25\% quinoa biscuit.

\begin{tabular}{lcccccc}
\hline & Appearance & Texture & Color & Taste & Flavor & Acceptability \\
\hline Control biscuit & $8.10 \pm 0.10 \mathrm{a}$ & $8.10 \pm 0.10 \mathrm{a}$ & $8.20 \pm 0.13 \mathrm{a}$ & $8.24 \pm 0.03 \mathrm{a}$ & $8.10 \pm 0.01 \mathrm{a}$ & $8.04 \pm 0.04 \mathrm{a}$ \\
$1212.5 \%$ quinoa biscuit & $8.10 \pm 0.10 \mathrm{a}$ & $8.00 \pm 0.01 \mathrm{a}$ & $7.80 \pm 0.15 \mathrm{a}$ & $8.00 \pm 0.00 \mathrm{a}$ & $7.90 \pm 0.10 \mathrm{~b}$ & $7.94 \pm 0.04 \mathrm{~b}$ \\
$25 \%$ quinoa biscuit & $7.70 \pm 0.15 \mathrm{~b}$ & $7.50 \pm 0.13 \mathrm{ba}$ & $7.60 \pm 0.16 \mathrm{~b}$ & $7.90 \pm 0.23 \mathrm{~b}$ & $7.90 \pm 0.18 \mathrm{~b}$ & $7.28 \pm 0.11 \mathrm{~b}$ \\
\hline
\end{tabular}

Mean values in each column having the same letter ( $\mathrm{a}$ and $\mathrm{b}$ ) are nonsignificantly different at $P>0.05$.

TABLE 8: Effect of the consumption of the $12.5 \%$ quinoa biscuit and $25 \%$ quinoa biscuit on body weight gain, weight gain $\%$, food intake, and FER compared to control biscuit in diabetic rat groups.

\begin{tabular}{lcccc}
\hline Groups & Body weight gain $(\mathrm{g})$ & Body weight gain $(\%)$ & Food intake $(\mathrm{g})$ & FER \\
\hline Positive control & $25.71 \pm 1.96 \mathrm{c}$ & $21.42 \pm 1.13 \mathrm{c}$ & $17.40 \pm 1.33 \mathrm{a}$ & $0.0246 \pm 0.002 \mathrm{c}$ \\
Control biscuit & $23.55 \pm 2.11 \mathrm{~cd}$ & $19.30 \pm 0.77 \mathrm{~cd}$ & $17.33 \pm 1.05 \mathrm{a}$ & $0.0226 \pm 0.001 \mathrm{~cd}$ \\
$12.5 \%$ quinoa biscuit & $51.78 \pm 4.66 \mathrm{~b}$ & $42.09 \pm 3.21 \mathrm{~b}$ & $17.55 \pm 1.21 \mathrm{a}$ & $0.0491 \pm 0.004 \mathrm{~b}$ \\
$25 \%$ quinoa biscuit & $65.41 \pm 5.40 \mathrm{a}$ & $53.17 \pm 4.03 \mathrm{a}$ & $18.99 \pm 1.10 \mathrm{a}$ & $0.0574 \pm 0.003 \mathrm{a}$ \\
\hline
\end{tabular}

Mean values in each column having the same letter ( $a$ and b) are nonsignificantly different at $P>0.05$.

addition of $50 \%$ or $100 \%$ quinoa flour addition biscuit formulations did not significantly change the biscuit properties compared to those made with wheat flour [43].

The results in Table 8 showed nonsignificant differences in body weight gain, body weight gain percent, and feed efficiency ratio (FER) between the diabetic positive rat group and the diabetic rat group that consumed control biscuit. On the other hand, the diabetic rat groups that consumed $12.5 \%$ quinoa biscuit and 25\% quinoa biscuit showed a significant increase in body weight gain, body weight gain percent, and FER compared with the positive rat group. Among the experimental rat groups, the highest improvement in nutritional value appeared in the diabetic rat group that consumed $25 \%$ quinoa biscuits because of elevated lipid, protein, fiber, polyphenol, and antioxidant values compared to the control biscuit. The digestibility and absorption of nutrients were improved by quinoa fiber intake $[44,45]$. Quinoa flour (QF) has been labelled a superfood because it contains more protein and has a better balanced amino acid composition than grain flours. QF is strong in protein, carbohydrate, fat, and fiber. Quinoa fiber is resistant to enzymatic digestion and absorption in the small intestine but generally ferments entirely or partially in the large intestine. Dietary fiber is regarded to be necessary for excellent digestive health as well as a number of physiological benefits. Dietary fiber has been shown to reduce cholesterol and fat absorption, change postprandial insulin response, increase endogenous cholesterol conversion to bile acids, improve intestinal microbiota, and reduce the incidence and severity of gastrointestinal infection and inflammation [41]. Several prior studies in vitro have demonstrated that quinoa protein digestibility is higher than wheat protein digestion, which adds to its high stomach accessibility and digestion, as well as its health benefits [46].

The consumption of the tested biscuits showed a nonsignificant difference in blood hemoglobin in diabetic rat groups. Rats that consumed in the control group showed nonsignificant differences in glycosylated hemoglobin, insulin, and glucose compared with the positive control diabetic rat group. Following consumption of $12.5 \%$ quinoa biscuits and $25 \%$ quinoa biscuits for 60 days, there was a decline in blood glycosylated hemoglobin and glucose and 
TABLE 9: Effect of consumption of the $12.5 \%$ quinoa biscuit and $25 \%$ quinoa biscuit on hemoglobin, glycosylated hemoglobin, insulin, and glucose compared to control biscuit in diabetic rat groups.

\begin{tabular}{lcccc}
\hline Groups & Hemoglobin $(\mathrm{g} / \mathrm{dl})$ & Glycosylated hemoglobin $(\%)$ & Insulin $(\mathrm{ng} / \mathrm{d})$ & Glucose $(\mathrm{mg} / \mathrm{dl})$ \\
\hline Positive control & $12.66 \pm 1.21 \mathrm{a}$ & $8.07 \pm 1.03 \mathrm{a}$ & $1.44 \pm 0.14 \mathrm{~cd}$ & $295.11 \pm 8.65 \mathrm{a}$ \\
Control biscuit & $12.77 \pm 1.09 \mathrm{a}$ & $7.96 \pm 0.78 \mathrm{ab}$ & $1.54 \pm 0.15 \mathrm{c}$ & $289.98 \pm 9.70 \mathrm{ab}$ \\
$12.5 \%$ quinoa biscuit & $13.75 \pm 1.22 \mathrm{a}$ & $6.11 \pm 0.69 \mathrm{c}$ & $2.08 \pm 0.30 \mathrm{~b}$ & $129.66 \pm 7.33 \mathrm{c}$ \\
$25 \%$ quinoa biscuit & $13.70 \pm 1.13 \mathrm{a}$ & $5.05 \pm 0.55 \mathrm{~d}$ & $2.97 \pm 0.42 \mathrm{a}$ & $105.71 \pm 5.14 \mathrm{~d}$ \\
\hline
\end{tabular}

Mean values in each column having the same letter ( $\mathrm{a}$ and $\mathrm{b}$ ) are nonsignificantly different at $P>0.05$.

an elevation in insulin compared with the positive control diabetic rat group. Moreover, the $25 \%$ quinoa biscuit rat group showed noticeable improvement in blood diabetic indicators, as shown in Table 9. The addition of quinoa flour to biscuits could increase the availability of fiber, which reduces the levels of blood lipids and glucose and elevates insulin sensitivity [47]. The intake of slowly digestible starches in whole grain flours from legumes and pseudocereals could lower glycemic indexes. The incorporation of quinoa flour into biscuits is beneficial in reducing glucose and increasing insulin without disturbing the nutritional balance owing to high phenol, fiber, and antioxidant activity. Quinoa seeds have anti-inflammatory, antioxidant, and antitumor actions due to the presence of valuable phenolic compounds [48-50].

\section{Conclusions}

Incorporation of quinoa flour is beneficial for biscuit production to improve the rheological, technological, and sensory properties of biscuits because of the higher quantity of dietary fiber in addition to high nutritional values (protein, fiber, and other bioactive antioxidant compounds) and therapeutic value due to the hypoglycemic effect.

4.1. Recommendations. Regarding the results of our study, it is recommended to fortify bakery products, especially biscuits with quinoa flour, and advise their consumption by diabetic patients. Further studies are needed to produce products fortified with quinoa and sugar alternatives for diabetic patients.

\section{Data Availability}

The data used to support the findings of this study are available from the corresponding author upon request.

\section{Additional Points}

Highlights. (i) Quinoa is a new crop species with high nutritional value, so it acts as a complete food. (ii) Quinoa is incorporated into wheat flour at a definite percentage for biscuit production. (iii) It has been of interest to increase the nutritional and sensory quality of biscuits by incorporating functional foods to decline blood glycosylated hemoglobin and glucose and for an elevation in insulin level in the diabetic rat group.

\section{Conflicts of Interest}

The authors declare no conflicts of interest.

\section{Acknowledgments}

This work was supported by Princess Nourah bint Abdulrahman University Researchers Supporting Project number (PNURSP2022R65), Princess Nourah bint Abdulrahman University, Riyadh, Saudi Arabia.

\section{References}

[1] K. Brady, C.-T. Ho, R. T. Rosen, S. Sang, and M. V. Karwe, "Effects of processing on the nutraceutical profile of quinoa," Food Chemistry, vol. 100, no. 3, pp. 1209-1216, 2007.

[2] F. D. Da Silva, C. F. Pante, S. H. Prudencio, and A. B. Ribeiro, "Establishment of a cereal bar with quinoa and its sensorial and nutritional properties/Elaboracao de uma barra de cereal de quinoa e suas propriedades sensoriais e nutricionais," Alimentos e Nutricao (Brazilian Journal of Food and Nutrition), vol. 22, no. 1, pp. 63-70, 2011, p.

[3] S. Comai, A. Bertazzo, L. Bailoni, M. Zancato, C. V. L. Costa, and G. Allegri, "The content of proteic and nonproteic (free and protein-bound) tryptophan in quinoa and cereal flours," Food Chemistry, vol. 100, no. 4, pp. 1350-1355, 2007, p.

[4] L. Alvarez-Jubete, M. Holse, A. Hansen, E. K. Arendt, and E. Gallagher, "Impact of baking on vitamin E content of pseudocereals amaranth, quinoa, and buckwheat," Cereal Chemistry, vol. 86, no. 5, pp. 511-515, 2009, p.

[5] R. Stikic, D. Glamoclija, M. Demin et al., "Agronomical and nutritional evaluation of quinoa seeds (Chenopodium quinoa Willd.) as an ingredient in bread formulations," Journal of Cereal Science, vol. 55, no. 2, pp. 132-138, 2012, p.

[6] N. M. Machado Alencar, C. J. Steel, I. D. Alvim, E. C. De Morais, and H. M. Andre Bolini, "Addition of quinoa and amaranth flour in gluten-free breads: temporal profile and instrumental analysis," LWT-Food Science and Technology, vol. 62, no. 2, pp. 1011-1018, 2015, p.

[7] V. Thejasri, T. V. Hymavathi, T. P. P. Roberts, B. Anusha, and S. S. Devi, "Sensory, physico-chemical and nutritional properties of gluten free biscuits formulated with quinoa (Chenopodium quinoa willd.), foxtail millet (setaria italica) and hydrocolloids," International Journal of Current Microbiology and Applied Sciences, vol. 6, no. 8, pp. 1710-1721, 2017, p.

[8] M. P. Tolaba, M. Peltzer, N. Enriquez, and M. Lućia Pollio, "Grain sorption equilibria of quinoa grains," Journal of Food Engineering, vol. 61, no. 3, pp. 365-371, 2004, p.

[9] A. Bhargava, S. Shukla, and D. Ohri, "Chenopodium quinoaAn Indian perspective," Industrial Crops and Products, vol. 23, no. 1 , pp. 73-87, 2006, p. 
[10] R. A.-M. Repo-Carrasco-Valencia and L. A. Serna, "Quinoa (Chenopodium quinoa, Willd.) as a source of dietary fiber and other functional components," Ciência e Tecnologia de Alimentos, vol. 31, no. 1, pp. 225-230, 2011, p.

[11] A. Atef, A. Abou-Zaid, E. Faham, S. Y. Wafaa, and H. Emam, "Use of quinoa meal to produce bakery products to celiac and autism stuffs," International Journal of Science and Research, vol. 3, no. 9, pp. 1344-1354, 2014.

[12] S. Keskin and K. A. Evlice, "Use of quinoa in bakery products," Journal of Field Crops Central Research Institute, vol. 24, no. 2, pp. 150-156, 2015.

[13] J. Ballester-Sánchez, M. C. Millan-Linares, M. T. FernandezEspinar, and C. M. Haros, "Development of healthy, nutritious bakery products by incorporation of quinoa," Foods, vol. 8, no. 379, pp. 1-13p, 2019.

[14] F. M. V. Farinazzi-Machado, S. M. Barbalho, M. Oshiiwa, R. Goulart, and O. Pessan Junior, "Use of cereal bars with quinoa (Chenopodium quinoa W.) to reduce risk factors related to cardiovascular diseases," Food Science and Technology, vol. 32, no. 2, pp. 239-244, 2012, p.

[15] M. L. Sudha, R. Vetrimani, and K. Leelavathi, "Influence of fibre from different cereals on the rheological characteristics of wheat flour dough and on biscuit quality," Food Chemistry, vol. 100, no. 4, pp. 1365-1370, 2007, p.

[16] J. Engleson and B. Atwell, "Gluten-free product development," Cereal Foods World, vol. 53, no. 4, pp. 180-185, 2008, p.

[17] Y. Hirose, T. Fujita, T. Ishii, and N. Ueno, "Antioxidative properties and flavonoid composition of Chenopodium quinoa seeds cultivated in Japan," Food Chemistry, vol. 119, no. 4, pp. 1300-1306, 2010, p.

[18] K. B. Ruiz, S. Biondi, R. Oses et al., "Quinoa biodiversity and sustainability for food security under climate change. A review," Agronomy for Sustainable Development, vol. 34, no. 2, pp. 349-359, 2014, p.

[19] M. Di Cairano, F. Galgano, R. Tolve, M. C. Caruso, and N. Condelli, "Focus on gluten free biscuits: ingredients and issues," Trends in Food Science \& Technology, vol. 81, pp. 203-212, 2018, p.

[20] P. G. Reeves, K. L. Rossow, and J. Lindlauf, "Development and testing of the AIN-93 purified diets for rodents: results on growth, kidney calcification and bone mineralization in rats and mice," Journal of Nutrition, vol. 123, no. 11, pp. 19231931, 1993, p.

[21] AACC, Approved methods of American association of cereal Chemists, AACC, Washington, DC, USA, 10th edition, pp. 26-95, Washington, DC, USA, 2000, Methods 10-10B.

[22] A. L. Waterhouse, "Determination of total phenolics," Current protocols in food analytical chemistry, vol. 6, no. 1, p. I1, $2002 \mathrm{p}$.

[23] A. Hosu, V.-M. Cristea, and C. Cimpoiu, "Analysis of total phenolic, flavonoids, anthocyanins and tannins content in Romanian red wines: prediction of antioxidant activities and classification of wines using artificial neural networks," Food Chemistry, vol. 150, pp. 113-118, 2014, p.

[24] J. Y. Chen, M. Piva, and T. P. Labuza, "Evaluation of water binding capacity (WBC) of food fiber sources," Journal of Food Science, vol. 49, no. 1, pp. 59-63, 1984.

[25] A. Hidalgo, A. Ferraretto, I. De Noni et al., "Bioactive compounds and antioxidant properties of pseudocerealsenriched water biscuits and their in vitro digestates," Food Chemistry, vol. 240, pp. 799-807, 2018, p.

[26] P. Wade, "Biscuit, cookies and crackers," Recipe of biscuit used during investigation, vol. 1, pp. 102-994, Applied Science Publishers LTD, London, UK, 1988.
[27] R. L. Murray, D. K. Granner, P. A. Mayes, and V. W. Rodwell, Harper's Biochemistry, Appleton and Lange Standord Connecticut, Stamford, CT, 25th edition, 2000.

[28] N. Enriquez, M. Peltzer, A. Raimundi, V. Tosi, and M. L. Pollio, "Characterization of wheat and quinoa flour blends in relation to their breadmaking quality," AnalesAsociacion Quimica Argentina, vol. 91, pp. 47-54, 2003.

[29] A. Sobota, M. Świeca, K. Gęsiński, A. Wirkijowska, and J. Bochnak, "Yellow-coated quinoa (Chenopodium quinoa Willd)-physicochemical, nutritional, and antioxidant properties," Journal of the Science of Food and Agriculture, vol. 100, no. 5, pp. 2035-2042, 2020.

[30] H. N. Ogungbenle, "Nutritional evaluation and functional properties of quinoa (Chenopodium quinoa) flour," International Journal of Food Sciences and Nutrition, vol. 54, no. 2, pp. 153-158, 2003, p.

[31] V. Melini and F. Melini, "Functional components and antinutritional factors in gluten-free grains: a focus on quinoa seeds," Foods, vol. 10, no. 2, p. 351, 2021.

[32] U. Gawlik-Dziki, M. Świeca, M. Sułkowski, D. Dziki, B. Baraniak, and J. Czyż, "Antioxidant and anticancer activities of Chenopodium quinoa leaves extracts-in vitro study," Food and Chemical Toxicology, vol. 57, pp. 154-160, 2013, p.

[33] V. R. de Souza, P. A. P. Pereira, T. L. T. Da Silva, L. C. De Oliveira Lima, R. Pio, and F. Queiroz, "Determination of the bioactive compounds, antioxidant activity and chemical composition of Brazilian blackberry, red raspberry, strawberry, blueberry and sweet cherry fruits," Food Chemistry, vol. 156, pp. 362-368, 2014, p.

[34] J. G. Lim, H. M. Park, and K. S. Yoon, "Analysis of saponin composition and comparison of the antioxidant activity of various parts of the quinoa plant (Chenopodium quinoa Willd.)," Food Sciences and Nutrition, vol. 8, no. 1, pp. 694-702, 2020.

[35] M. Mhada, M. L. Metougui, K. El Hazzam, K. El Kacimi, and A. Yasri, "Variations of saponins, minerals and total phenolic compounds due to processing and cooking of quinoa (Chenopodium quinoa Willd.) seeds," Foods, vol. 9, no. 5, p. 660, 2020.

[36] C. Berti, P. Riso, L. D. Monti, and M. Porrini, "In vitro starch digestibility and in vivo glucose response of gluten-free foods and their gluten counterparts," European Journal of Nutrition, vol. 43, no. 4, pp. 198-204, 2004, p.

[37] A. Torbica, M. Hadnađev, and T. Dapčević, "Rheological, textural and sensory properties of gluten-free bread formulations based on rice and buckwheat flour," Food Hydrocolloids, vol. 24, no. 6-7, pp. 626-632, 2010, p.

[38] M. Föste, S. D. Nordlohne, D. Elgeti et al., "Impact of quinoa bran on gluten-free dough and bread characteristics," European Food Research and Technology, vol. 239, no. 5, pp. 767-775, 2014, p.

[39] S. Sarabhai and P. Prabhasankar, "Influence of whey protein concentrate and potato starch on rheological properties and baking performance of Indian water chestnut flour based gluten free cookie dough," Lebensmittel-Wissenschaft und -Technologie- Food Science and Technology, vol. 63, no. 2, pp. 1301-1308, 2015, p.

[40] T. R. D. Hadnađev, A. M. Torbica, and M. S. Hadnađev, "Influence of buckwheat flour and carboxymethyl cellulose on rheological behaviour and baking performance of gluten-free cookie dough," Food and Bioprocess Technology, vol. 6, no. 7, pp. 1770-1781, 2013, p.

[41] A. M. M. Filho, M. R. Pirozi, J. T. D. S. Borges, H. M. Pinheiro Sant'Ana, J. B. P. Chaves, and J. S. D. R. Coimbra, "Quinoa: 
nutritional, functional, and antinutritional aspects," Critical Reviews in Food Science and Nutrition, vol. 57, no. 8, pp. 1618-1630, 2017.

[42] B. Sazesh and M. Goli, "Quinoa as a wheat substitute to improve the textural properties and minimize the carcinogenic acrylamide content of the biscuit," Journal of Food Processing and Preservation, vol. 44, no. 8, Article ID e14563, 2020.

[43] N. M. Harra, T. Lemm, C. Smith, and D. Gee, "Quinoa flour is an acceptable replacement for all-purpose flour in a peanut butter cookie," Journal of the American Dietetic Association, vol. 111, no. 9, p. A45, 2011.

[44] L. E. A. James, "Quinoa (Chenopodium quinoa Willd.): composition, chemistry, nutritional, and functional properties," Advances in Food and Nutrition Research, vol. 5, no. 9, pp. 1043-4526, 2009, p.

[45] R. I. Stikić, D. D. Milinčić, A. Ž. Kostić et al., "Polyphenolic profiles, antioxidant, and in vitro anticancer activities of the seeds of Puno and Titicaca quinoa cultivars," Cereal Chemistry, vol. 97, no. 3, pp. 626-633, 2020.

[46] R. A. M. Repo-Carroso-Valencia and L. A. Serna, "Quinoa (Chenopodium quinoa, Willd.) as a source of dietary fiber and other functional components," Ciência e Tecnologia de Alimentos, vol. 31, pp. 225-230, 2011.

[47] J. L. R. Ascheri, C. R. Spehar, and R. E. Nascimento, "Comparative chemical characterization of instantaneous flours by extrusion-cooking from quinoa (Chenopodium quinoa Willd.), corn and rice," Alimentaria, vol. 331, pp. 89-92, 2002.

[48] G. Giuberti and A. Gallo, "Reducing the glycaemic index and increasing the slowly digestible starch content in gluten-free cereal-based foods: a review," International Journal of Food Science and Technology, vol. 53, no. 1, pp. 50-60, 2018, p.

[49] G. Rocchetti, G. Giuberti, and L. Lucini, "Gluten-free cerealbased food products: the potential of metabolomics to investigate changes in phenolics profile and their in vitro bioaccessibility," Current Opinion in Food Science, vol. 22, pp. 1-8, 2018, p.

[50] M. Liu, K. Zhu, Y. Yao et al., "Antioxidant, anti-inflammatory, and antitumor activities of phenolic compounds from white, red, and black Chenopodium quinoa seed," Cereal Chemistry, vol. 97, no. 3, pp. 703-713, 2020. 